\title{
Tendency and distribution indices for ordinal variables applied to Ellenberg indicator values
}

\section{Índices de tendencia y distribución para variables ordinales aplicados a valores indicadores de Ellenberg}

\author{
Miguel Alvarez ${ }^{1}$, Bodo Maria Möseler ${ }^{1} \&$ Cristina San Martín²* \\ ${ }^{1}$ Vegetation Ecology, INRES, University of Bonn, Nussallee 9, D-53115 Bonn, Germany. \\ ${ }^{2}$ Instituto de Ciencias Ambientales y Evolutivas, Universidad Austral de Chile, Casilla 567, Campus Isla Teja, Valdivia, Chile. \\ *csanmart@uach.cl
}

\begin{abstract}
The use of mean value for the analysis of Ellenberg indicator values in plots or plant community types has been criticised by several authors. On the other hand, little attention has been paid to distribution patterns of the respective classes frequencies. Herewith we make a revision of metrics available for the characterization of tendency and distribution patterns of ordinal variables, like in the case of Ellenberg indicator values, and discuss their relation to frequency histogram shapes. We selected three tendencies (mean value, median value and mode) and two distribution metrics (position index and relative dominance). Additionally, we proposed a concentration index, which is analogous to the contagion index commonly used by landscape ecologists. According to our observations, we recommend the use of the median value and the concentration index to quantify respectively the tendency and distribution patterns on indicator spectra (frequency histograms) according to the Ellenberg indicator values. Further studies are required to get better ecological interpretations in the distribution patterns of indicator spectra.
\end{abstract}

KEYWORDS: Bio-indicators, ecological monitoring, grassland vegetation, species composition.

\begin{abstract}
RESUMEN
El uso del valor promedio en el análisis de valores indicadores de Ellenberg en censos o comunidades vegetales ha sido criticado por varios autores. Por otro lado, se ha prestado poca atención a los patrones de distribución de las clases de frecuencia. En este trabajo se hace una revisión sobre métricas disponibles para cuantificar tendencia y distribución en escalas ordinales, como es el caso de los indicadores ecológicos de Ellenberg y discutir su relación con las formas de los histogramas de frecuencia respectivos. Para ello se eligieron tres métricas de tendencia (valor promedio, mediana y moda) y dos métricas de distribución (índice de posición y dominancia relativa). Además se propone el índice de concentración que es análogo al índice de contagio usado en ecología de paisaje. En este trabajo se recomienda el uso de la mediana y el índice de concentración para cuantificar respectivamente la tendencia y la distribución en espectros de indicadores (histogramas de frecuencia) calculados en base a los valores de Ellenberg. Se requieren estudios adicionales para lograr una mejor interpretación ecológica de los patrones de distribución mencionados en este trabajo.
\end{abstract}

Palabras clave: Bioindicadores, monitoreo ecológico, pastizales, composición florística.

\section{INTRODUCTION}

Vascular plant species growing in natural communities normally occur within a limited range of abiotic conditions (Wamelink et al. 2005). This specific range is known as "ecological response" and can be alternatively expressed as "ecological optimum" for the occurrence or growth of a single species (Ellenberg et al. 2001). Thus species composition of plant communities reflects the environmental condition of the respective habitats. Biological indication is using the response of organisms to their environment and has being widely applied in plant ecology, forestry and agriculture (Diekmann 2003). One of the most popular systems of bioindication in vegetation ecology is the Ellenberg's approach (for the $3^{\text {rd }}$ edition see Ellenberg et al. 2001). This system is based on the ecological response of plants 
to seven different environmental factors, three of them concerning climate (light, temperature and continentality) and four concerning soil conditions (soil moisture, reaction or acidity, nitrogen content and salinity). Those responses are expressed as "indicator values" in an ordinal (semiquantitative) scale ranging from 1 to 9 , with the exception of soil moisture that ranges from 1 to 12 in order to include riparian and aquatic plants. Ellenberg's indicator values were originally proposed for Central Europe, nevertheless they have been adapted to other regions in the world: Thompson et al. (1993) for the British Islands, Ertsen et al. (1998) for the Netherlands, Diekmann (1995) for Sweden, Godefroid \& Dana (2007) for Italy and Greece, Lawesson et al. (2003) for the Faroe Islands, Ramírez et al. (1991, 1992) and San Martín et al. (2003, 2009) for Chile. Besides the applications of Ellenberg indicator values as a rapid and cost saving environmental assessment, they can be also integrated to more complex assessment and monitoring strategies (e.g. Blüthgen et al. 2012).

As mentioned by Ellenberg et al. (2001), the mean indicator value of all species occurring in the analysed unit will be calculated to build the "indicator figure". Each indicator figure can be calculated qualitatively (using presence-absence datasets) or quantitatively (weighting the values by the cover or abundance of each species). The use of arithmetic average to calculate indicator figures has being often criticised, since those values are ordinal scaled (e.g. Dierschke 1994) and the distribution of classes (levels of the values) in a sampling unit is not necessarily normal (Möller 1992). Despite these criticisms, this is a very common practice (e.g. Diekmann \& Dupré 1997, Schaffers \& Sýkora 2000, Seidling \& Fischer 2008, Schmidt \& Streit 2009). Ellenberg et al. (2001) stated that their indicator values are equidistant segmentation of the numerical scales (at least for the variables temperature, continentality, soil nitrogen content and salinity), allowing the calculation of means. This is also supported by the high correlations found between indicator figures and directly measured environmental factors (e.g. Melman et al. 1988, Thompson et al. 1993, Diekmann 1995, Ertsen et al. 1998, Schaffers \& Sýkora 2000, Roy et al. 2000).

For a graphical representation of Ellenberg indicator values in plant communities or species assemblages is the use of frequency histograms. Those histograms are called "indicator spectra" (e.g. Ewald 2007) and are able to display both, the dominance of single classes and the distribution of frequencies among classes (Dierschke 1994, Ellenberg et al. 2001). Little attention has being paid to the distribution of indicator values within plots or vegetation units, while most of the studies assume a priori a unimodal distribution. Deviations of indicator spectra from unimodal distributions can be attributed to rapid shifts in the environmental conditions. In a study on German pine forest stands, Ewald (2007) suggested that bimodal distribution of Ellenberg indicator values for soil nitrogen content $(\mathrm{N})$ may indicate an abrupt eutrophication of the soil. He encourages the check of spectra and modality of indicator frequencies in vegetation relevés as a standard practice.

Regarding the criticism to the use of mean value to calculate indicator figures of vegetation samples (relevés) or plant community types (syntaxa) and the necessity for surveys on ecological interpretations of frequency distribution patterns of indicator spectra, we make herewith a revision on metrics available to quantify those attributes, in order to make them suitable for further studies. Those values will be applied to hypothetical as well as to observed indicator spectra.

\section{MATERIAL AND METHODS}

HypotheticAl AND OBSERVED DISTRIBUtion PATTERNS OF INDICATOR VALUES

Unimodal are the most typical distribution of Ellenberg indicator values in plant communities. Nevertheless we may also expect the occurrence of other patterns depending on the presence of disturbance events (changes in soil chemical properties or water content and other anthropogeneous effects), the importance of the analysed environmental factor in the determination of species composition, and the scale of sampling units (plant sociological relevés, transects, landscape units). For instance, Ewald (2007) suggested that a rapid switch from nutrient deficiency to excess in a plant community may generate bimodal indicator spectra due to rapid changes in the species composition. We also would expect either erratic or homogeneous distributions for plant communities dominated by pioneer species, occurring by chance and not necessarily responding to any other environmental variable than low competition. Therefore we designed five hypothetical distribution patterns that may be easily recognized by visual inspection: unimodal symmetric, unimodal asymmetric (skewed to the higher values), bimodal, erratic, and homogeneous. Those distributions were arbitrarily drafted in order to get the desired histogram shapes and represent ordinal variables with 9 levels as most of the Ellenberg indicator values (Fig. 1).

In order to analyse distributions of real data, we used a dataset of 148 relevés recorded in plant communities from North Rhine-Westphalia and Rhineland-Palatinate (Germany). Those relevés consist on records of all vascular plant species occurring within plots of 1 to $25 \mathrm{~m}^{2}$ size, depending on the vegetation type (Table I). The abundance of each species in the relevé was estimated visually as percentage cover. The sampled relevés were classified into 4 plant sociological associations called here as Eleocharito-Caricetum (Eleocharito-Caricetum bohemicae Klika 1935, class Isoëto-Nanojuncetea), GentianoKoelerietum (Gentiano-Koelerietum pyramidetae Knapp ex 
Bornkamm 1960, class Festuco-Brometea), Mesobrometum (Brometum Scherrer 1925, class Festuco-Brometea), and Alliario-Chaerophylletum (Alliario-Chaerophylletum temuli Lohmeyer 1949, class Galio-Urticetea). Since the associations are defined by their species composition, habitat conditions and physiognomy (Dierschke 1994), this classification is more adequate to our purposes. Those associations belong respectively to pioneer ephemeral dwarf vegetation on seasonal flooded soils (EleocharitoCaricetum), meso-xerophytic swards (GentianoKoelerietum and Mesobrometum) and thermophilous anthropogenic vegetation dominated by nutrient demanding tall-herbs (Alliario-Chaerophylletum) (Pott 1995, Rodwell et al. 2002).

In order to calculate the indicator figures for each association, we stored in our dataset the indicator values for light $(\mathrm{L})$, temperature $(\mathrm{T})$, continentality $(\mathrm{K})$, soil humidity $(\mathrm{F})$, soil reaction $(\mathrm{R})$ and soil nitrogen content $(\mathrm{N})$ from Ellenberg et al. (2001). For each indicator value and each association we drew mean histograms (indicator spectra) using as frequency of each class the ratio of the cumulative percentage cover of all species assigned to the class, to the total sum of covers in the association. Species without indicator values (symbol " $X$ " in Ellenberg et al. 2001) were not considered for the calculation of the total sum of covers.

\section{TENDENCY AND DISTRIBUTION PARAMETERS}

The most used tendency parameter for indicator values is the mean value. Since the mean value as indicator figure is questionable, as discussed before, a better alternative is the use of the median value, as encouraged by Möller (1992). A third tendency parameter is the mode, which may match the median value when an indicator spectrum is strongly dominated by one class or when the distribution is unimodal and symmetric.

Low attention has been paid to the distribution of the indicator values within relevés or associations (Ewald 2007). Distribution parameters as standard deviation and variance quantify spread of values in a dataset, but they are also restricted to cardinal scales with normal distribution. Möller (1992) proposed to use the position of the median in the corresponding median class as additional information
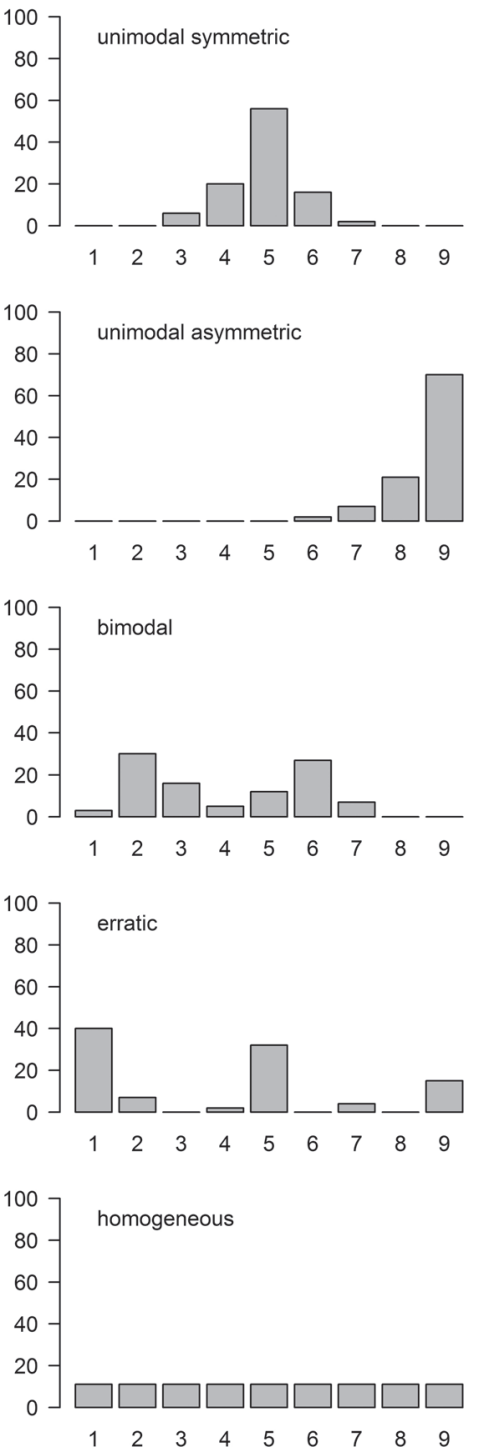

FIgURE 1. Hypothetical indicators spectra with contrasting distribution patterns. Those patterns are arbitrarily designed for this study.

Figura 1. Espectros indicadores hipotéticos con patrones de distribución contrastantes. Estos patrones fueron diseñados en forma arbitraria para este estudio.

TABLE I. Plot size, amount of samples and number of species recorded in each studied association.

TABLA I. Área, cantidad de muestras y número de especies registradas en cada asociación vegetal estudiada.

\begin{tabular}{|c|c|c|c|c|}
\hline \multirow{2}{*}{ Association } & \multirow{2}{*}{ Plot size $\left(\mathrm{m}^{2}\right)$} & \multirow{2}{*}{ Number of Plots } & \multicolumn{2}{|c|}{ NUMBER OF SPECIES } \\
\hline & & & MEAN & TOTAL \\
\hline Eleocharito-Caricetum & 1 & 13 & 13.8 & 32 \\
\hline Gentiano-Koelerietum & 25 & 90 & 40.9 & 179 \\
\hline Mesobrometum & 25 & 26 & 38.8 & 124 \\
\hline Alliario-Chaerophylletum & 10 & 19 & 13.3 & 79 \\
\hline
\end{tabular}


to the indicator figure. The calculation of this index follows the equation:

$$
P I=2(\text { rel pos }-0.5)
$$

where $P I$ is the position index and rel pos is the position of median in median's class expressed as ratio (for a graphical explanation, see Fig. 2). This index is related to the symmetry of the spectra outside of the median's class and shows the probability of wrong selection of the median by chance, instead the lower class (PI tends to -1) or the higher class (PI tends to 1).

In a similar context but analysing the distribution of constancy classes (also ordinal scaled) Lausi \& Feoli (1979) proposed the use of the evenness. A counter value of the evenness is the dominance index currently used for the quantification of landscape patterns (O'Neill et al. 1988). The dominance index expresses the probability that two random selected elements of a dataset belong to the same class. Of course, this makes only sense in the case of frequencies of individuals and in the analysis of relative abundance it has only a descriptive relevance. In this work, we propose a modification of the dominance index of O'Neill et al. (1988) by calculating the relative dominance according to the following formula:

$$
R D=1+\frac{\sum\left(f_{i} \ln f_{i}\right)}{\ln S}
$$

where $R D$ is the relative dominance, $f_{i}$ is the relative abundance of all species with the $i t h$ class, and $S$ is the amount of classes ( 9 for most of the Ellenberg's indicator values). After this modification, the dominance index varies between 0 (all classes with the same relative frequency in the vegetation unit) and 1 (absolute dominance of one class).

One shape characteristic of spectra not considered by the previous indices is the degree of concentration of frequencies close to the median. This aspect can be partially reflected by dominance index, but its calculation does not consider the location of classes along the ordinal scale. We propose therefore a concentration index $(C I)$, calculated by following formula:

$$
C I=\sum \frac{f_{i}}{\mid i-\text { median } \mid+1}
$$

here $f_{i}$ is the relative frequency of the class $i$, and median is the calculated indicator figure according to the median value. This index varies between 0 and 1 , with higher values for frequencies concentrated near the median and lower values for more spread distributions. Relative dominance is analogous to the contagion index used to quantify landscape patterns (O’Neill et al. 1988).
To test the behaviour of all mentioned indices, we performed their calculations in both, hypothetical and observed indicator spectra. Herewith, calculations and plotting routines were carried out using the programming language $\mathrm{R}$ version 2.14.2 (R Development Core Team 2012).

\section{RESULTS}

VALUES IN HYPOTHETICAL INDICATOR SPECTRA

Regarding hypothetical distributions, tendency indices (mean value, median value and mode) have similar values in unimodal distributions, while in the bimodal, erratic and homogeneous distributions those indices tend to differ from each other (Table II). The position index have in most of the cases a negative value indicating that the median is proximal to its next lower class. This trend is extreme in the case of the erratic distribution (position index $=-0.94)$. Despite those general trends, we do not expect any relation between the values of position index and the shape of an indicator spectrum. An exception to it is the homogeneous distribution, when applied to uneven amount of classes, where the position index will tend to a zero value, as shown in Table II. By definition, relative dominance and concentration indices have higher values in unimodal distribution, while the lowest value belongs to the homogeneous distribution.

OBSERVED VALUES AND SHAPE OF MEAN INDICATOR SPECTRA Considering the mean indicator spectra of collected relevés, we can visually recognize a high diversity of shapes (Fig. 3), like for instance strong unimodal distributions (indicator $\mathrm{T}$ for all associations), bimodal distributions (indicator $\mathrm{K}$ for Gentiano-Koeleretum and Mesobrometum) and erratic distributions (indicators $\mathrm{R}$ and $\mathrm{N}$ in Eleocharito-Caricetum). Those shapes are reflected in the values of relative dominance and concentration index (Table III).

Tendency metrics can be interpreted as the environmental (ecological) dimension of the studied associations. Conspicuous differences are the low L values and high $\mathrm{N}$ values for Alliario-Chaerophylletum, indicating that those plant communities are shadow-tolerant and typical of eutrophic soils, while the high $\mathrm{F}$ values of Eleocharito-Caricetum indicate higher soil humidity for those communities. The position index acquire indifferently positive or negative values, but high absolute values of this index are related with distributions without an absolute dominance of one class, like the more homogeneous distributions in the indicator $\mathrm{K}$ for Eleocharito-Caricetum and Gentiano-Koelerietum or in the spectra of the same associations plus Mesobrometum for the factor F. 


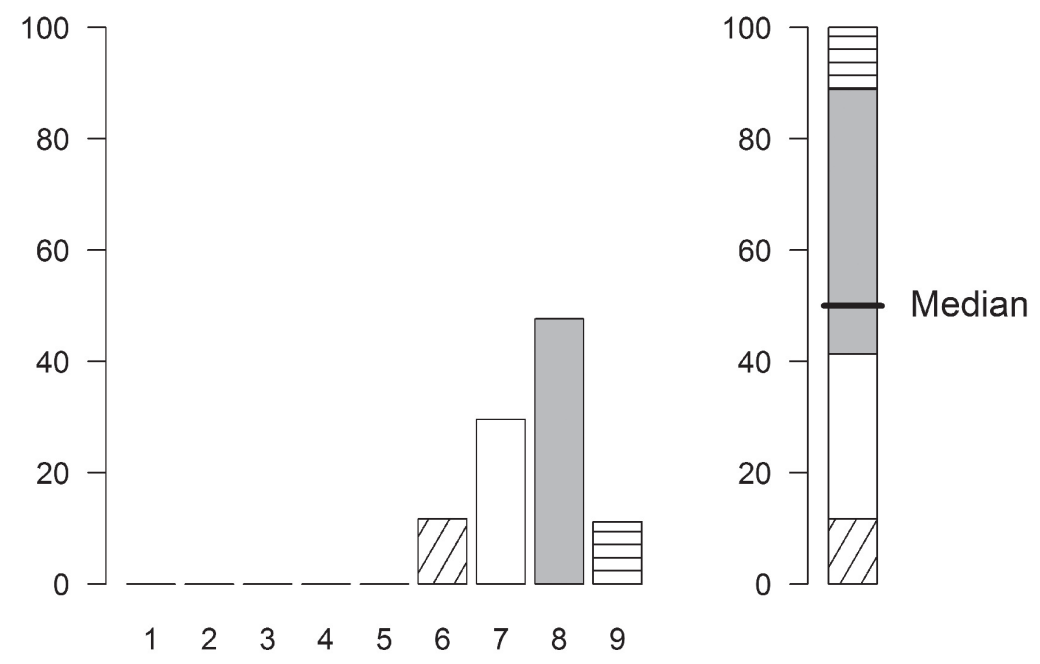

Figure 2. Calculation of the median using the indicator values for the factor light (L) in the association Eleocharito-Caricetum. Adding the frequencies of the indicator classes the cutline on $50 \%$ determines the value 8 as median. The relative position of the median in the median's class is 0.185 and the position index, -0.63 .

FIGURA 2. Cálculo de la mediana usando las clases de valores indicadores para el factor luz (L) en la asociación Eleocharito-Caricetum. La línea que corta al $50 \%$ de la suma de frecuencias determina el valor 8 como mediana. La posición relativa de la mediana en dicha clase (8) es 0,185 y el índice de posición, $-0,63$.

TABLE II. Values of tendency and distribution indices for hypothetical indicators spectra. Respective histograms are shown in Fig. 1.

TABLA II. Valores de los índices de tendencia y distribución para espectros indicadores hipotéticos. Los histogramas respectivos se muestran en la Fig. 1.

\begin{tabular}{|c|c|c|c|c|c|c|}
\hline Distribution & $\begin{array}{l}\text { MEAN } \\
\text { VALUE }\end{array}$ & $\begin{array}{l}\text { MEdian } \\
\text { VALUE }\end{array}$ & Mode & $\begin{array}{l}\text { Position } \\
\text { INDEX }\end{array}$ & $\begin{array}{c}\text { Relative } \\
\text { DOMINANCE }\end{array}$ & $\begin{array}{c}\text { CONCENTRATION } \\
\text { INDEX }\end{array}$ \\
\hline unimodal symmetric & 4.88 & 5 & 5 & -0.143 & 0.460 & 0.767 \\
\hline unimodal asymmetric & 8.59 & 9 & 9 & -0.429 & 0.617 & 0.833 \\
\hline bimodal & 4.02 & 4 & 2 & -0.600 & 0.225 & 0.405 \\
\hline erratic & 3.85 & 5 & 1 & -0.938 & 0.359 & 0.471 \\
\hline homogeneous & 5.00 & 5 & 1 & 0.000 & 0.000 & 0.396 \\
\hline
\end{tabular}



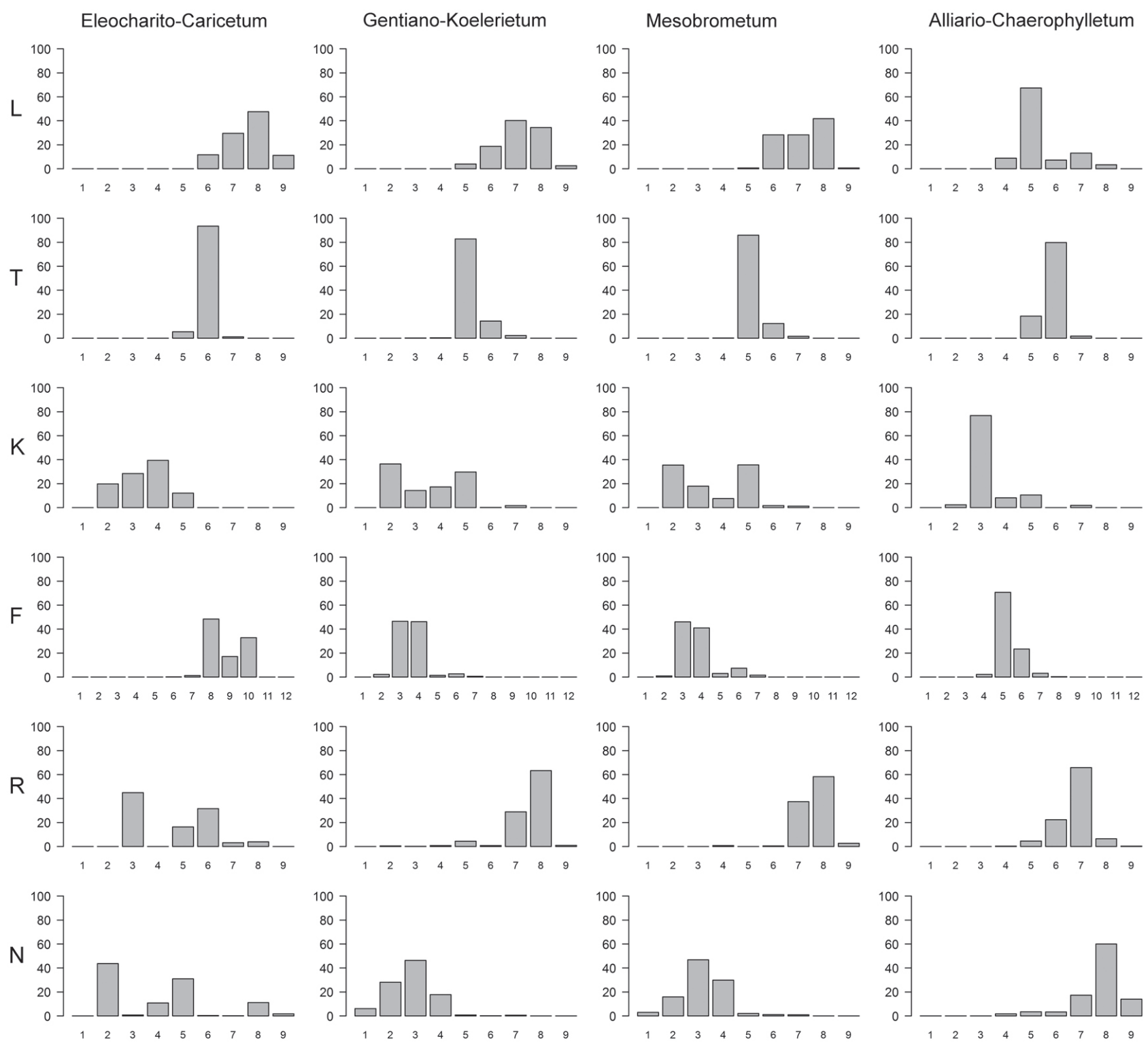

FIGURE 3. Observed indicators spectra of four plant communities (columns) and six environmental parameters (rows). Predicted parameters are light $(\mathrm{L})$, temperature $(\mathrm{T})$, continentality $(\mathrm{K})$, soil humidity $(\mathrm{F})$, soil reaction $(\mathrm{R})$, and soil nitrogen content $(\mathrm{N})$. Frequencies are shown as relative cover percentage.

FIGURA 3. Espectros indicadores observados para cuatro comunidades vegetales (columnas) y seis parámetros ambientales (filas). Los parámetros estimados son luz $(\mathrm{L})$, temperatura $(\mathrm{T})$, continentalidad $(\mathrm{K})$, humedad edáfica $(\mathrm{F})$, reacción del suelo $(\mathrm{R})$ y contenido en nitrógeno del suelo $(\mathrm{N})$. Las frecuencias se muestran como porcentajes de cobertura relativa. 
Distribution indices of Ellenberg indicator values: ALVAREZ, M. ET AL.

TABLE III. Values of tendency and distribution indices for observed indicator spectra applied to six environmental parameters and four associations.

TABLA III. Valores de los índices de tendencias y distribución para los espectros indicadores observados, aplicados a seis parámetros ambientales y a cuatro asociaciones vegetales.

\begin{tabular}{|c|c|c|c|c|c|c|}
\hline SyntaXa & $\begin{array}{l}\text { MEAN } \\
\text { VALUE }\end{array}$ & $\begin{array}{l}\text { Median } \\
\text { VALUE }\end{array}$ & Mode & $\begin{array}{l}\text { Position } \\
\text { INDEX }\end{array}$ & $\begin{array}{c}\text { Relative } \\
\text { DOMINANCE }\end{array}$ & $\begin{array}{c}\text { CONCENTRATION } \\
\text { INDEX }\end{array}$ \\
\hline & L: light & & & & & \\
\hline Eleocharito-Caricetum & 7.6 & 8 & 8 & -0.63 & 0.45 & 0.72 \\
\hline Gentiano-Koelerietum & 7.1 & 7 & 7 & 0.35 & 0.42 & 0.69 \\
\hline Mesobrometum & 7.1 & 7 & 8 & 0.47 & 0.47 & 0.64 \\
\hline \multirow{2}{*}{ Alliario-Chaerophylletum } & 5.3 & 5 & 5 & 0.22 & 0.52 & 0.81 \\
\hline & $\mathrm{T}$ : temper & & & & & \\
\hline Eleocharito-Caricetum & 6.0 & 6 & 6 & -0.05 & 0.88 & 0.97 \\
\hline Gentiano-Koelerietum & 5.2 & 5 & 5 & 0.20 & 0.75 & 0.91 \\
\hline Mesobrometum & 5.2 & 5 & 5 & 0.16 & 0.79 & 0.93 \\
\hline \multirow[t]{2}{*}{ Alliario-Chaerophylletum } & 5.8 & 6 & 6 & -0.21 & 0.74 & 0.90 \\
\hline & $\mathrm{K}$ : contine & & & & & \\
\hline Eleocharito-Caricetum & 3.4 & 4 & 4 & -0.91 & 0.40 & 0.66 \\
\hline Gentiano-Koelerietum & 3.5 & 3 & 2 & 0.88 & 0.36 & 0.52 \\
\hline Mesobrometum & 3.5 & 3 & 5 & 0.61 & 0.38 & 0.52 \\
\hline \multirow[t]{2}{*}{ Alliario-Chaerophylletum } & 3.4 & 3 & 3 & 0.24 & 0.63 & 0.86 \\
\hline & F: soil hur & & & & & \\
\hline Eleocharito-Caricetum & 8.8 & 9 & 8 & -0.98 & 0.56 & 0.58 \\
\hline Gentiano-Koelerietum & 3.6 & 4 & 3 & -0.95 & 0.60 & 0.72 \\
\hline Mesobrometum & 3.7 & 4 & 3 & -0.85 & 0.54 & 0.69 \\
\hline \multirow[t]{2}{*}{ Alliario-Chaerophylletum } & 5.3 & 5 & 5 & 0.35 & 0.68 & 0.85 \\
\hline & R: soil rea & lkalinity/ & & & & \\
\hline Eleocharito-Caricetum & 4.6 & 5 & 3 & -0.38 & 0.43 & 0.49 \\
\hline Gentiano-Koelerietum & 7.5 & 8 & 8 & -0.55 & 0.57 & 0.80 \\
\hline Mesobrometum & 7.6 & 8 & 8 & -0.62 & 0.61 & 0.79 \\
\hline \multirow[t]{2}{*}{ Alliario-Chaerophylletum } & 6.7 & 7 & 7 & -0.31 & 0.56 & 0.82 \\
\hline & N: soil nit & ontent & & & & \\
\hline Eleocharito-Caricetum & 4.0 & 4 & 2 & 0.01 & 0.38 & 0.44 \\
\hline Gentiano-Koelerietum & 2.8 & 3 & 3 & -0.32 & 0.42 & 0.72 \\
\hline Mesobrometum & 3.2 & 3 & 3 & 0.32 & 0.41 & 0.72 \\
\hline Alliario-Chaerophylletum & 7.7 & 8 & 8 & -0.20 & 0.46 & 0.78 \\
\hline
\end{tabular}




\section{DISCUSSION}

Tendency indices calculated in this work seem to be congruent with the ecological descriptions of the studied associations. For instance, Alliario-Chaerophylletum comprises plant communities of forest fringes, while the resting associations belong to open vegetation (Pott 1995, Rodwell et al. 2002), explaining the higher L values for the former association. Additionally, Alliario-Chaerophylletum grows over eutrophic soils (Pott 1995, Rodwell et al. 2002) and has therefore a high $\mathrm{N}$ value. Similar is the case of the association Eleocharito-Caricetum, occurring in seasonal wetlands (Müller-Stoll \& Pietsch 1985, Pott 1995) and therefore with a higher humidity value (F) than the other terrestrial associations. The sward associations GentianoKoelerietum and Mesobrometum occur in meso-xeric, oligogrophic soils developed from limestone (Pott 1995). Those properties result in a relatively low value for soil humidity (F), high value for soil reaction (R) and low value for soil nitrogen content $(\mathrm{N})$. Despite the higher precision of the mean value (expressed to tenths in Table III), ecological characterisation of associations is possible by using median value and will be recommended by us as more proper tendency metric for Ellenberg indicator values. On the other hand, mode may be suitable to quantify tendency in nominal scaled variables (e.g. life forms, chorological groups, etc.).

The position index is relatively independent of the shape of indicator spectra. Its absolute value is related with the proximity of the median to the next class, while its sign indicates whether the median is closer to the next higher (positive sign) or next lower class (negative sign) (Möller 1992). This metric could be helpful to know with more detail how different were two distributions, but does not convey much information about the indicator spectra shape. On the contrary, relative dominance and concentration index are better related with the degree of unimodality. Herewith the concentration index is more adequate for ordinal scaled variables, while the relative dominance is suitable for nominal scaled variables.

Deviation of indicator spectra from unimodal one may have an ecological relevance (Ewald 2007). Since this phenomenon is underexplored, more detailed studies comparing indicator spectra with direct measured environmental variables are required. In this work, the degree of unimodality seems not only to depend on the associations studied (e.g. high unimodality in Alliario-Chaerophylletum for all variables) but also on studied variable (e.g. high unimodality for temperature in all communities). In our case, erratic patterns for the association Eleocharito-Caricetum in the variables soil reaction (R) and soil nitrogen content (N) as well as a bimodal trend for soil humidity (F) can be related to the dynamic of this ephemeral vegetation (Deil 2005) and the strong introgression of species belonging to the neighbouring plants communities, which occur under different environmental conditions. Such plant communities affecting the species composition of Eleocharito-Charicetea may belong to the pioneer vegetation of mesotrophic, periodically flooded fringes of water bodies (class Bidentetea tripartiti) or neighbouring ephemeral vegetation belonging to the class Isoëto-Littorelletea (Pott 1995, Rodwell et al. 2002).

\section{ACKNOWLEDGEMENTS}

Many of the ideas expressed here were consolidated during the successive visits to the Meeting on Vegetation Databases and the International Workshop of European Vegetation Survey. Some of those visits were financed by the Federal Agency for Nature Conservation (BfN). We also thank to two anonymous referees for their constructive comments to a first version of this manuscript.

\section{REFERENCES}

Blüthgen, N., D.F. Dormann, D. Prati, V.H. Klaus, T. Kleinebecker, N. Hölzel, F. Alt, S. Boch, S. Gockel, A. Hemp, J. Müller, J. Nieschulze, S.C. Renner, I. Schöning, U. Schumacher, S.A. Socher, K. Wells, K. Birkhofer, F. Buscot, Y. Oelmann, C. Rothenwöhrer, C. Scherber, T. Tscharntke, C.N. Weiner, M. Fischer, E.K.V. Kalko, K.E. Linsenmair, E.-D. Schulze \& W.W. Weisser. 2012. A quantitative index of land-use intensity in grassland: integrating mowing, grazing and fertilization. Basic and Applied Ecology 13: 207-220.

DeIL, U. 2005. A review on habitats, plant traits and vegetation of ephemeral wetlands - a global perspective. Phytocoenologia 35: 533-705.

Diekmann, M. 1995. Use and improvement of Ellenberg's indicator values in deciduous forests of the Boreo-nemoral zone in Sweden. Ecography 18: 178-189.

Diekmann, M. \& C. Dupré. 1997. Acidification and eutrophication of deciduous forests in northwestern Germany demonstrated by indicator species analysis. Journal of Vegetation Science 8: 855-864.

Diekmann, M. 2003. Species indicator values as an important tool in applied plant ecology - a review. Basic and Applied Ecology 4: 193-506.

DierschKe, H. 1994. Pflanzensoziologie. Eugen Ulmer, Stuttgart. $683 \mathrm{pp}$.

Ellenberg, H., H.E. Weber, R. Düll, V. Wirth \& W. Werner. 2001. Zeigerwerte von Pflanzen in Mitteleuropa. Erich Goltze, Göttingen. 262 pp.

Ertsen, A.C.D., J.R.M. Alkemade \& M.J. Wassen. 1998. Calibrating Ellenberg indicator values for moisture, acidity, nutrient availability and salinity in the Netherlands. Plant Ecology 135: 113-124.

EwALD, J. 2007. Bimodal spectra of nutrient indicators reveal abrupt eutrophication of pine forests. Preslia 79: 391-400.

Godefroid, S. \& E.D. Dana. 2007. Can Ellenberg's indicator values for Mediterranean plants be used outside their 
region of definition? Journal of Biogeography 34: 62-68.

Lausi, D. \& E. Feoli. 1979. Hierarchical classification of European salt marsh vegetation based on numerical methods. Vegetatio 39: 171-184.

Lawesson, J. E., A. M. FosaA \& E. Olsen. 2003. Calibration of Ellenberg indicator values for the Faroe Islands. Applied Vegetation Science 6: 53-62.

Melman, T.C.P., P.H.M.A. Clausman \& H.A.U. de Haes. 1988. The testing of three indicator systems for trophic state in grasslands. Vegetatio 75: 143-152.

Möller, H. 1992. Zur Verwendung des Medians bei Zeigerwertberechnungen nach Ellenberg. Tuexenia 12: 25-28.

Müller-Stoll, W.R. \& W. Pietsch. 1985. Ökologische Untersuchungen über die gesellschaft des EleocharitoCaricetum bohemica auf wasserfrei gewordenen Teichböden in Zentraleuropa. Verhandlungen der Zoologisch-Botanischen Gesellschaft in Osterreich 123: 51-70.

O`Neill, R.V., J.R. Krummel, R.H. Gardner, G. Sugihara, B. Jackson, D.L. De Angelis, B.T. Milne, M.G. Turner, B. Zygmunt, S.W. Christensen, V.H. Dale \& R.L. Graham. 1988. Indices of landscape pattern. Landscape Ecology 1: 153-162.

Potт, R. 1995. Die Pflanzengesellschaften Deutschlands. Eugen Ulmer, Stuttgart. $622 \mathrm{pp}$.

R Development Core Team. 2012. R: a language and environment for statistical computing. R Foundation for Statistical Computing, Vienna. URL: http://cran.r-project.org

Ramírez, C., V. L. Finot, C. San Martín \& A. Ellies. 1991. El valor indicador ecológico de las malezas del centro-sur de Chile. Agro Sur 19: 94-116.

Ramírez, C., C. San Martín, V. Finot \& D. Ríos. 1992. Evaluación de praderas usando indicadores ecológicos. Agro Sur 20: 85-100.

Rodwell, J.S., J.H.J. Schaminée, L. Mucina, S. Pignatti, J. Dring
\& D. Moss. 2002. The diversity of European vegetation. EC-LNV, Wageningen. 168 pp.

Roy, D.B., M.O. Hill, P. Rothery \& R.G.H. Bunce. 2000. Ecological indicator values of British species: an application of Gaussian logistic regression. Annales Botanici Fennici 37: 219-226.

San Martín, C., C. Ramírez \& M. Alvarez. 2003. Macrófitos como bioindicadores: Una propuesta metodológica para caracterizar ambientes dulciacuícolas. Revista Geográfica de Valparaíso 34: 243-253.

San Martín, C., C. Villagra \& C. Novoa. 2009. Comparación de manejos pratenses del centro-sur de Chile utilizando bioindicadores de Ellenberg. Gayana Botanica 66: 158170.

Schaffers, A.P. \& K.V. SÝKora. 2000. Reliability of Ellenberg indicator values for moisture, nitrogen and soil reaction: a comparison with field measurements. Journal of Vegetation Science 11: 225-244.

Schmidt, W. \& M. Streit. 2009. Gibt es einen Zusammenhang zwischen der Diversität der Baumschicht und der Bodenvegetation? - Untersuchungen in BuchenEdellaubholz-Mischwäldern des Göttinger Waldes (Süd-Niedersachsen, Deutschland). Waldökologie, Landschaftsforschung und Naturschutz 7: 5-19.

Seidling, W. \& R. Fischer. 2008. Deviances from expected Ellenberg indicator values for nitrogen are related to $\mathrm{N}$ throughfall deposition in forests. Ecological Indicators 8: 639-646.

Thompson, K.,J.G. Hodgson, J.P. Grime, I.H. Rorison, S.R. BAnd \& R.E. SPEncER. 1993. Ellenberg numbers revisited. Phytocoenologia 23: 277-289.

Wamelink, G.W.W., P.W. Goedhart, H.F. van Dobben \& F. Berendse. 2005. Plant species as predictors of soil $\mathrm{pH}$ : replacing expert judgement with measurements. Journal of Vegetation Science 16: 461-470.

Recibido: 23.11.12

Aceptado: 19.04.13 